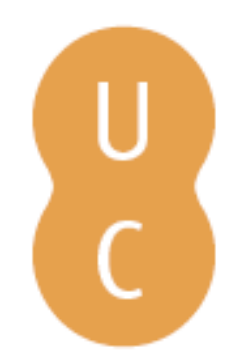

\title{
pompalina
}

\section{Behaviours related to fair-play in english and spanish professional football players}

Autor(es): $\quad$ Cruz, Jaume; Torregrosa, Miquel; Boixadós, Mercé

Publicado por: Imprensa da Universidade de Coimbra

URL

persistente: URI:http://hdl.handle.net/10316.2/32257

DOI: $\quad$ DOI:http://dx.doi.org/10.14195/978-989-26-0474-9_13

Accessed : $\quad$ 26-Apr-2023 08:07:34

A navegação consulta e descarregamento dos títulos inseridos nas Bibliotecas Digitais UC Digitalis, UC Pombalina e UC Impactum, pressupõem a aceitação plena e sem reservas dos Termos e Condições de Uso destas Bibliotecas Digitais, disponíveis em https://digitalis.uc.pt/pt-pt/termos.

Conforme exposto nos referidos Termos e Condições de Uso, o descarregamento de títulos de acesso restrito requer uma licença válida de autorização devendo o utilizador aceder ao(s) documento(s) a partir de um endereço de IP da instituição detentora da supramencionada licença.

Ao utilizador é apenas permitido o descarregamento para uso pessoal, pelo que o emprego do(s) título(s) descarregado(s) para outro fim, designadamente comercial, carece de autorização do respetivo autor ou editor da obra.

Na medida em que todas as obras da UC Digitalis se encontram protegidas pelo Código do Direito de Autor e Direitos Conexos e demais legislação aplicável, toda a cópia, parcial ou total, deste documento, nos casos em que é legalmente admitida, deverá conter ou fazer-se acompanhar por este aviso. 
Carlos Eduardo Gonçalves

Sean P. Cumming

Manuel J. Coelho e Silva

Robert M. Malina

(Editors)

\section{Sport \\ and Education}

Oribute to OMaxtin Lee

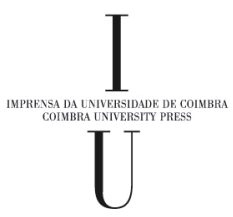


Jaume Cruz, Miquel Torregrosa, Mercé Boixadós

Auton. Univ. Barcelona, Spain

\section{BEHAVIOURS RELATED TO FAIR-PLAY IN ENGLISH AND SPANISH PROFESSIONAL FOOTBALL PLAYERS ${ }^{(*)}$}

\section{Introduction}

In professional competitive sports, every player or team tries to be superior to the opponent, following a set of written rules which define how the game has to be played. These rules have been labelled as Constitutive rules, and are accepted by every player to play fairly the competition. Moreover, there are also a second type of rules labelled Normative rules that may differ across the different sports and reflect the values' system established by players, coaches, managers and fans. Some normative rules, such as kick the ball off to help a player on the ground in a soccer match, favour fair play. However, other normative rules imply intentional violations of constitutive rules to achieve some benefits for the team, such as, in soccer, to stop an opponent in the midfield, when he has the opportunity of creating a dangerous opening. These behaviours are called "useful" or "tactical" fouls, and some sport scientists have suggested that some of rule violating behaviours, including aggressive player behaviour, are normative behaviours perceived as legitimate by participants (e.g., Silva 1981, 1983; Vaz 1979). Consequently, socialisation process in sport will legitimate rule violating behaviour in professional and youth sports, unless sports leaders modify sport rules to state that rule violating behaviour will become dysfunctional to sport success. In this chapter, contact faults, behaviours against fair play, and behaviours in favour of fair play were assessed in 24 football matches of English Premiere League (PL) and the Spanish Liga de Futbol Profesional (LFP).

Studies about violence and aggression, specially violence between spectators of a professional contact sports like football, prevailed in the eighties in Sport Psychology and Sociology as a result of serious riots produced by football hooligans (Dunning, Murphy, \& Williams, 1988; Goldstein, 1983; Murphy, Williams \& Dunning, 1990; Rimé \& Leyens, 1988; Smith, 1983). In fact, some authors like Russell (1993) suggested that outside wartime, sport is perhaps the only setting in which acts of interpersonal aggression are not only tolerated but enthusiastically applauded by large segments of society.

$\left(^{*}\right)$ This work has been partly founded with the grant BSO2003-04301 and DEP2006-56013 from Plan Nacional de I+D. 
Violence in sport, both on and off the field, has come to be perceived as a social problem as Tenenbaum, Stewart, Singer and Duda (1997) have outlined in an International Society of Sport Psychology -ISSP- position stand about aggression and violence in sport. As a result of these trends, commissions have been created in different countries to investigate violence in the athletic setting and studies about attitudes, values and behaviours related to fair play and moral development of youth athletes have received greater attention in Sport Psychology (e.g., Bredemeier, 1994; Lee \& Cokman, 1995; Shields \& Bredemeier, 1994).

As Lee (1996) pointed out, the bulk of research into fair play have been attitudinal studies, (e.g., Blair 1985; Boixadós \& Cruz, 1995; Case, Greer \& Lacourse, 1987; Goodger \& Jackson, 1985; Lee \& Williams, 1989; Pilz, 1995). The results of these studies suggest that instrumental attitudes are more commonly associated with older athletes, higher level of organised sport participation, amount of physical contact and males rather than females (Pilz, 1995; Silva, 1983).

Although the value systems of sports participants are fundamental for an adequate understanding of fair play, there had been few studies about values in sport, until the research initiative of the Council of Europe and the Sports Council, coordinated by Professor Martin Lee, in the late 1980s stimulated interest in this area (Cruz, Boixadós, Valiente \& Capdevila, 1995; Lee, 1993; Lee \& Cokman, 1995; Lee, Whitehead \& Balchin, 2000; Mielke \& Bahlke, 1995; and Torregrosa \& Lee, 2000). Results of the aforementioned studies provide further evidence to doubt about the positive influence that simply playing sport has in fair play, sportsmanship and character development (see Shields \& Bredemeier 2001 for a review). Hence more research has to be done in the social environment in which sport is presented to young athletes in order to assess its potential for promoting desirable ethical standards.

Since youth sport is often derived from professional models, it is reasonable to assume that the behaviours of professional players would affect junior practice. So in this chapter an observational register of behaviours related to fair play in football matches is presented, in order to assess these behaviours in a sample of matches of the Premiere League-PL- and the Liga de Fútbol Profesional -LFP- (Spanish Football League).

The observational tool used in this research comes from a multidimensional definition of fair play incorporating: (a) Respect for rules, (b) Good relationships with opponents, (c) Equality of opportunities and conditions, (d) Avoidance of victory at all costs, (e) Honour in victory and defeat, and (f) personal commitment to do one's best (Boixadós \& Cruz, 1995). In essence, we agree with Lee's definition of fair play as: "particular behaviours characterised by the principle of justice for all, in which there is no attempt to gain an unfair advantage over an opponent either purposefully or fortuitously" (Lee, 1996). According to the previous definition, we have elaborated an observational register with different behavioural categories grouped in 3 main blocks: contact faults, behaviours against fair play and behaviours in favour of fair play (see Table 1 and 2).

\section{Method}

\subsection{Sample}

Twenty-four football matches, 12 of the Liga de Fútbol Profesional-LFP-(Spain) and 12 of the Premiere League -PL- (England). The reason why the sample is composed 
by matches and not persons is that they are the main information units, that is, when we study behaviours related to fair play, we analyse what happens in every match, without emphasising who have done it. As a consequence, we have data about player's behaviours related with fair play of 24 football matches and data about referees' performance in those matches (faults, cards, etc.).

\subsection{Procedure}

The main instrument used in this research is the observational register of behaviours related with fair play in football matches designed by our research team (Cruz et al., 1996) and used in previous works (Cruz, Boixadós, Valiente \& Torregrosa, 2001; Palou, Borràs, Ponseti, Garcia-Mas \& Cruz, 2003; Torregrosa \& Cruz, 1999; Torregrosa, Mimbrero, Boixadós \& Cruz, 1996). The observational register allows the registration of 18 behaviours grouped in three blocks: contact faults, behaviours in favour of fair play and behaviours against fair play. Moreover, the observational register allows the registration of the minute in which behaviour takes place and the order of occurrence. Table 1 shows an example of the observational register and Table 2 presents the operational definitions of the eighteen categories.

Table 1: Observational register.

\begin{tabular}{|c|c|c|c|c|c|c|c|c|c|c|}
\hline \multirow{2}{*}{ Categories } & \multicolumn{2}{|c|}{ Minute 0} & \multicolumn{2}{|c|}{ Minute 1} & \multicolumn{2}{|c|}{ Minute 2} & \multicolumn{2}{|c|}{ Minute 3} & \multicolumn{2}{|c|}{ Minute 4} \\
\hline & & G & $\mathrm{H}$ & G & $\mathrm{H}$ & G & $\mathrm{H}$ & G & $\mathrm{H}$ & G \\
\hline \multicolumn{11}{|l|}{ 1. Kick/Trip } \\
\hline \multicolumn{11}{|l|}{ 2. Push/Hold down } \\
\hline \multicolumn{11}{|l|}{ 3. Block } \\
\hline \multicolumn{11}{|l|}{ 4. Hit } \\
\hline \multicolumn{11}{|l|}{ 5. Dangerous Play } \\
\hline \multicolumn{11}{|l|}{ 6. Deliberate hands } \\
\hline \multicolumn{11}{|l|}{ 7. Protest } \\
\hline \multicolumn{11}{|l|}{ 8. Lose time deliberately } \\
\hline \multicolumn{11}{|l|}{ 9. Don't return the ball } \\
\hline \multicolumn{11}{|l|}{ 10. Trick } \\
\hline \multicolumn{11}{|l|}{ 11. Aggression } \\
\hline \multicolumn{11}{|l|}{ 12. Don't accept excuses } \\
\hline \multicolumn{11}{|l|}{ 13. Accept excuses } \\
\hline \multicolumn{11}{|l|}{ 14. Apologise } \\
\hline \multicolumn{11}{|l|}{ 15. Kick out the ball } \\
\hline \multicolumn{11}{|l|}{ 16. Return the ball } \\
\hline \multicolumn{11}{|l|}{ 17. Jump over the goalkeeper } \\
\hline \multicolumn{11}{|l|}{ 18. Encourage the opponent } \\
\hline \multicolumn{11}{|l|}{ 19. Others } \\
\hline Incidences (goals, cards,...) & & & & & & & & & & \\
\hline
\end{tabular}


Football matches were recorded on video tapes and three independent observers watched them after. At the moment of behaviours' notation in the observational register tapes were stopped in order to prevent the lost of reactive behaviours.

Table 2: Operational definition of the categories.

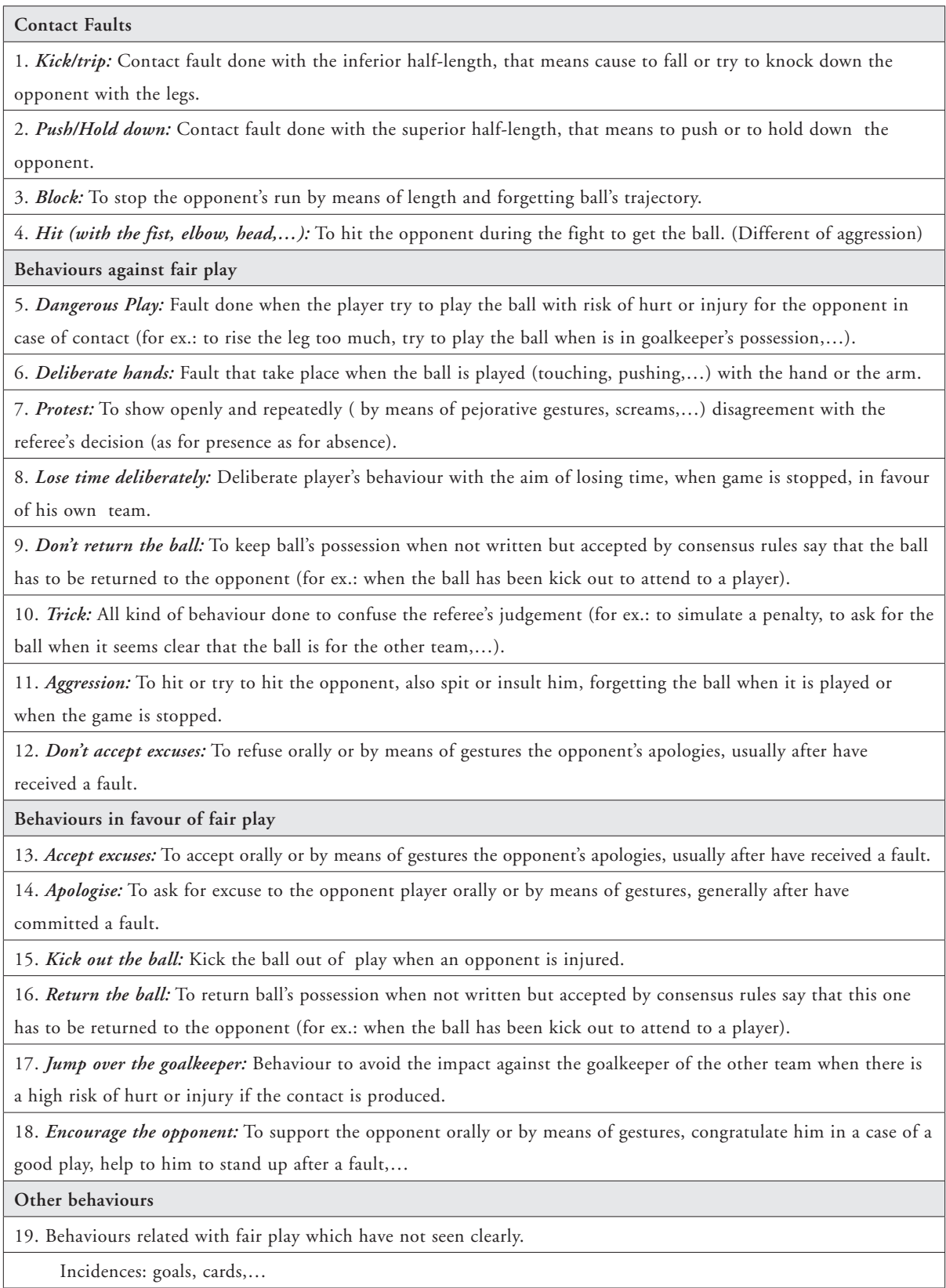




\section{Results}

Figure 1 shows means of blocks of behaviours (contact faults, behaviours against and behaviours in favour of fair play) for the $L F P$ and the PL. For each block appear more behaviours in case of LFP than in case of PL. Moreover, in all cases the difference is statistically significant $(\mathrm{p}<0,001)$. In our sample, more contact faults, more behaviours against fair play and more behaviours in favour of fair play were observed in case of $L F P$ than in case of $P L$.

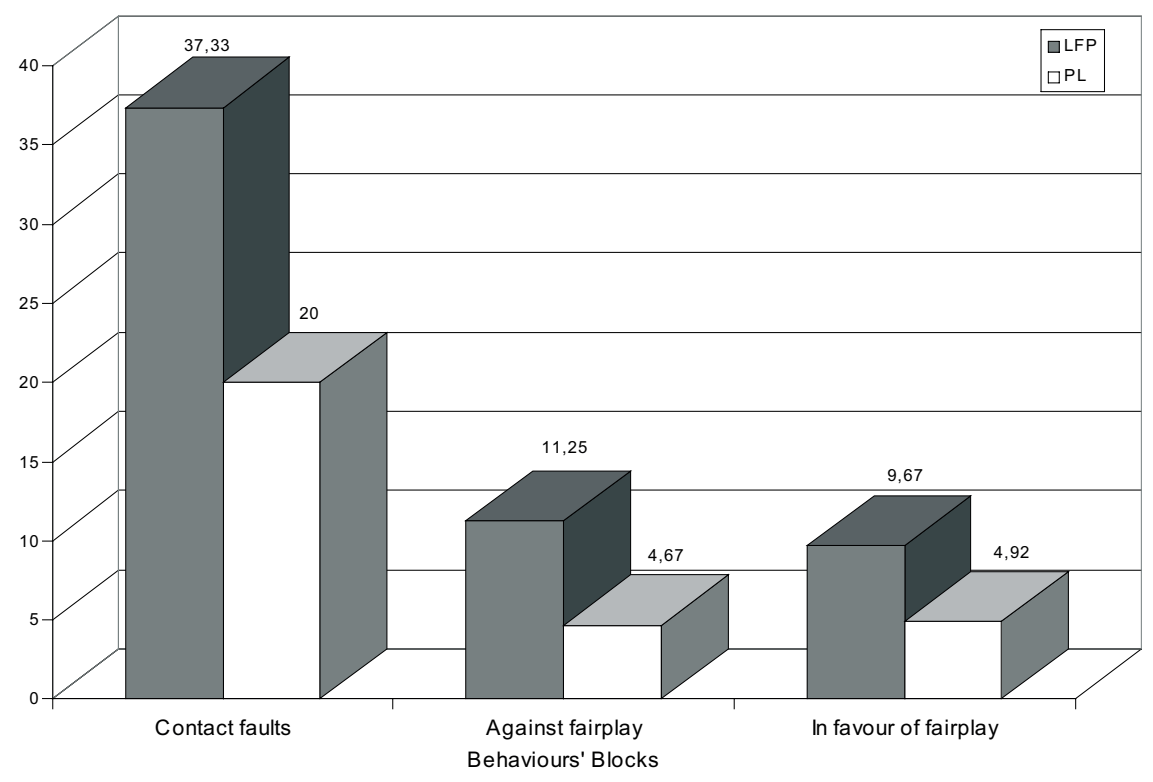

Figure 1: Means by match of behaviours blocks for the LFP and the PL.

Table 3 shows in which categories are significant the differences observed in the blocks. Behaviours grouped as contact faults (Kick, Push, Block and Hit) present all of them differences in the sense indicated by blocks of categories. That is, significant more behaviours of those categories are observed in the LFP than in the PL. Referring to behaviours against fair play, differences are centred in the categories Dangerous play $(\mathrm{p}=0.042)$, and Protest $(\mathrm{p}<0.001)$. The means by its own are illustrative data if we take into account that in the LFP appears a mean of nearly 6 protests every match while in the PL appears less than 2. Referring to favourable to fair play behaviours, significant differences are concentrated in the categories Kick out the ball and Return the ball. These behaviours are in fact a sequence of behaviours in a fair play environment (always the first appears, appears also the second). Moreover, although 
they are framed in the block of behaviours favourable to fair play, the appearance of a higher mean can not always be interpreted positively for two reasons. On the one hand, the behaviour of Kicking out the ball is produced generally when a player needs assistance, that is, usually after a fault or behaviour against fair play. On the other hand, every time that ball is off the field the game is stopped and the real time of play decreases. Therefore, there are not significant differences in the categories Jump over the goalkeeper and Encourage the opponent, those categories with less possibility of a negative antecedent.

Table 3: Means by categories of behaviours related with fair play and statistical significance of the differences

\begin{tabular}{lccc}
\hline & LFP & $P L$ & Significance \\
\hline Kick/Trip & 19.42 & 10.17 & $\mathrm{p}<0.001$ \\
Push/Hold down & 16.00 & 9.42 & $\mathrm{p}<0.001$ \\
Block & 1.33 & 0.33 & $\mathrm{p}=0.039$ \\
Hit & 0.58 & 0.08 & $\mathrm{p}=0.008$ \\
Dangerous play & 0.92 & 0.33 & $\mathrm{p}=0.042$ \\
Deliberate hands & 1.42 & 1.50 & $\mathrm{p}=0.832$ \\
Protest & 5.92 & 1.83 & $\mathrm{p}<0.001$ \\
Lose time deliberately & 1.08 & 0.25 & $\mathrm{p}=0.090$ \\
Don't return the ball & 0 & 0 & \\
Trick & 0.33 & 0.17 & $\mathrm{p}=0.514$ \\
Aggression & 1.50 & 0.58 & $\mathrm{p}=0.289$ \\
Don't accept excuses & 0.08 & 0.00 & $\mathrm{p}=0.328$ \\
Accept excuses & 1.08 & 0.50 & $\mathrm{p}=0.147$ \\
Apologise & 2.33 & 1.33 & $\mathrm{p}=0.088$ \\
Kick out the ball & 1.00 & 0.17 & $\mathrm{p}=0.005$ \\
Return the ball & 1.00 & 0.33 & $\mathrm{p}=0.028$ \\
Jump over the goalkeeper & 0.33 & 0.50 & $\mathrm{p}=0.544$ \\
Encourage the opponent & 3.91 & 2.08 & $\mathrm{p}=0.097$ \\
\hline
\end{tabular}

In our research, we began also to assess the role of referees maintaining and/or promoting fair play. Table 4 shows means and statistical significance of the differences in yellow and red cards between the LFP and the PL. When differences are calculated in each league, we can see that the mean of yellow cards shown by the Spanish referees is statistically higher than the mean of yellow cards shown by the English referees $(M=6.5$ vs. $M=4 ; p=0.023)$. This means that results of referees are consistent with those of the player's behaviours. Therefore, if we have found first that Spanish players make more faults and more behaviours against fair play, is consistent to find that Spanish referees shows more cards than the English ones. Referring to red cards, no significant differences between leagues were found. 
Table 4: Means by match of yellow and red cards and statistal significance between both competitions.

\begin{tabular}{l|c|c|c}
\hline & LFP & PL & Significance \\
\hline Yellow Cards & 6.5 & 4 & $\mathrm{p}=0.023$ \\
Red Cards & 0.58 & 0.25 & $\mathrm{p}=0.167$ \\
\hline
\end{tabular}

The differences found in player's behaviours, suggest the possibility that apart of appearing more cards in the LFP the cause for showing them can be different in each league. For this reason we have analysed the cause of each card. In case of the $L F P, 60$ of the total 78 yellow cards (that is $77 \%$ ) were shown after a contact fault committed by some player, and 18 yellow cards (that is the $23 \%$ ) were shown as a consequence of behaviour against fair play. In case of $P L, 37$ of the 48 yellow cards (that is 77\%) were shown after a contact fault committed by some player, and 11 yellow cards (that is the $23 \%$ ) were shown as a consequence of behaviour against fair play. In summary, we can appreciate that significant more yellow cards are shown in the LFP comparing with the $P L$, but the cause of these cards is distributed equally in both leagues.

\section{Discussion}

Quantitative analysis of behaviours related with fair play has shown that $L F P$ players have done more faults $(M=37.33$ vs. $M=20)$, more behaviours against fair play $(M=11.25$ vs. $M=4.67)$ and more behaviours in favour of fair play $(M=9.67$ vs. $\mathrm{M}=4.92$ ) than $P L$ players. If we consider the results of contact faults and behaviours against fair play, we could think that in $L F P$ the matches are played with less fair play than in $P L$. However, considering the behaviours in favour of fair play we could conclude the opposite. How can we explain these results that seem contradictory? Does it mean that the play is rougher in $L F P$ than $P L$ ? Or is it softer? Certainly, to answer these questions more researches are necessary but, from our point of view we adventure two possible explanations. The first one comes from our observational instrument and the second one arises from the qualitative analysis of the matches.

Due to the categorisation some of the behaviours in favour of fair play (Apologise, Kick out the ball, Return the ball) are linked with contact faults. In fact, these are the categories in which differences between $L F P$ and $P L$ are statistically significant. This means that with the appearance of more contact faults also appears more behaviours in favour of fair play. However, this doesn't allow us to conclude that matches in one of both competitions are played with more or less fair play. In future researches, we plan to separate behaviours in favour of fair play into 2 groups: those ones with a positive or neutral antecedent (for example Encourage the opponent) and those ones with a negative antecedent (for example Apologise after a fault).

The number of contacts between football players is basically the same in both leagues. The main difference is player's reaction after receiving the contact. Whereas in $L F P$ players usually ends on the field, in $P L$ players try to go on playing. This could be related with the difference between constitutive and normative rules (Silva, 1981). 
Due to the fact that constitutive rules are equal for both competitions (there is only one official rules), the difference has to be in the normative rules, those ones not written but accepted by participants' consensus (players, referees, coaches and spectators). For example, it seems more accepted in the LFP to gain ball's possession using all kind of tricks, simulations, etc. to take advantage from the opponent. However, in the $P L$ this kind of tricks or simulations are less usual. This one could be an example which, added to other differences, let us consider the existence of different 'cultures' in the world of football or different ways of understanding football in different countries.

Analysis of referees' performance is a first step to go deeper in the understanding of fair play as a global matter which depends of all participants in sportive situation (Cruz, et al., 2001; Torregrosa \& Cruz, 1999). In this sense, we plan also in the future to investigate coaches, managers and media role in fair play exhibited by players in football matches and the pressure they put on referees. Results of this study show that in Liga de Fútbol Profesional referees admonish statistically more than in Premiere League $(P L)$, but referees are not the unique responsible of this fact. The faults marked during a professional football match and its consequent admonitions are responsibility of players and referees. As a consequence of the major number of faults in the LFP than in $P L$ is quite normal to find more admonitions in the Spanish league ( $L F P=6,5$ vs. $P L=4)$ and this difference is statistically significant. Moreover is interesting to confirm that distribution of admonishes antecedents are the same in both leagues, about $77 \%$ after a contact fault and $23 \%$ as a consequence of a behaviour against fair play.

Our results show that winning at all costs has become an essential part of modern professional sport everywhere, but results obtained from $P L$ players are more favourable to fair play that those obtained in $L F P$. However, there is always room for improvement in the models offered by both leagues and some actions should be taken in the future in order to improve not only fair play and sportsmanship but also the sportive spectacle by its own. These measures will be important to ensure a better fair play in professional sport and to offer better models for youth sports.

In summary, our belief is that in professional sport, there exists a so called "informal system of norms" which allows players rule violations in the interest of success in sport. Pilz (1995) points out that rule violations are legitimated and expected by fans, so a dangerous circle, difficult to interrupt, starts. Players commits faults in the interest of winning the match. Spectators expect players commit some kind of fouls and reinforce them by making "useful or tactical" faults. Expectations of players and spectators could by different in the studied leagues depending on the differences between football's "culture".

In conclusion, two kinds of actions are needed to promote fair play and sportsmanship. First of all changes in rules in order to avoid transgressors advantage during the game. Actually, professional players don't behave according to a principle of justice for all, but they act within a simple cost-profit calculation principle. So, as long as the costs for unfair behaviour are less than the profits obtained, they will use these behaviours to attain their goals of success, as Pilz (1995), Silva (1981) and Stornes (2001) have outlined. In second place, a long term educational measures for all the participants (players, coaches, referees, managers, etc.) in youth football -such as those summarised in different codes of sports ethics- have to be initiated (e.g., Borras, 2004). These two kinds of measures are necessary to prevent the increase of utilitarian behaviours in 
top level football players and the imitation of negative models in youth sports, due to the influence that significant others have in the shaping of the moral atmosphere of youth sport teams, as have been outlined by different research teams (Boixadós, Cruz, Torregrosa, \& Valiente 2004; Guivernau and Duda ,2002; Ommundsen, Roberts, Lemyre \& Treasure, 2003; Shields, Bredemeier, LaVoi \& Power (2005), Stephens \& Bredemeier, 1996).

\section{References}

Blair S (1985). Professionalisation of attitude towards play in children and adults. Research Quarterly, 56 (1), 82-83.

Boixadós M, Cruz J (1995). Evaluación del fairplay en futbolistas jóvenes. [Fair play’s assessment in young football players]. Revista Española de Educación Física y Deportes, 2(3), 13-22.

Boixados M, Cruz J, Torregrosa M, Valiente L. (2004). Relationships among motivational climate, satisfaction, perceived ability, and fair play attitudes in young soccer players. Journal of Applied Sport Psychology 16 (4), 301-317.

Borràs P (2004). Intervenció per a la promoció de l'esportivitat en el futbol cadet a Mallorca. [Intervention to promote sportpersonship in youth football in Mallorca]. Unpublished doctoral dissertation. Universitat Illes Balears.

Bredemeier BJ (1994). Children's moral reasoning and their assertive, aggressive, and submissive tendencies in sport and daily life. Journal of Sport and Exercise Psychology, 16, 1-14.

Case BW, Greer HS, Lacourse MG (1987). Moral judgement development and perceived legitimacy of spectator behaviour. Journal of Sport Behaviour. 10, (3) 147-156.

Cruz J, Boixadós M, Valiente L, Capdevila L (1995). Prevalent values in young Spanish soccer players. International Review for the Sociology of Sport, 30, 353- 373.

Cruz J, Boixadós M, Valiente L, Torregrosa M (2001). ¿Se pierde el fairplay y la deportividad en el deporte en edad escolar?.[Is youth sport loosing fair play and sportsmanship?] Apunts. Educación Física y Deportes, 64, 6-16.

Cruz J, Capdevila L, Boixadós M, Pintanel M, Alonso C, Mimbrero J, Torregrosa M (1996). Identificación de conductas, actitudes y valores relacionados con el fair play en deportistas jovenes.[Identification of behaviours, attitudes and values related to fair play in youth athletes]. In Valores sociales y deporte: fair play versus violencia. (pp.37-67). Madrid: Consejo Superior de Deportes.

Dunning EP, Murphy P, Williams J (1988). The roots of football hooliganism. University of Leicester Press. England: Leicester.

Guivernau M, Duda JL (2002). Moral atmosphere and athletic aggressive tendencies in young soccer players. Journal of Moral Education, 31 (1), 67-85.

Goldstein JH, Ed. (1983). Sport violence. New York: Springer-Verlag .

Goodner MJ, Jackson JJ (1985). Fair Play: Coaches' attitudes towards the laws of soccer. Journal of Sport Behavior. 8 (1), 34-41.

Lee MJ (1993). Moral development and children's sporting values. In J.Whitehead (Ed.) Development Issues in Children's Sport and Physical Education, (pp. 30-42). Bedford: Bedford College of Higher Education.

Lee MJ (1996). Young people, sport and ethics: an examination of fair play in youth sport. Technical report of the Sports Council Research Unit: London.

Lee MJ, Cockman MJ (1995). Values in children's sport: Spontaneously expressed values among young athletes. International Review for the Sociology of Sport, 30/3-4, 337-352. 
Lee MJ, Whitehead J, Balchin N (2000). The measurement of values in youth sport: development of the youth sports values questionnaire. Journal of Sport and Exercise Psychology, 22, 307-326.

Lee MJ, Williams V (1989). Over de top. Sport and Leisure, March-April 27-28.

Mielke R, Bahlke S (1995). Structure and preferences of fundamental values of young athletes do they differ from non-athletes and from young people with alternative leisure activities? International Review for the Sociology of Sport, 30, 420-437.

Murphy P, Williams J, Dunning EP (1990). Football on trial. London: Routledge.

Ommundsen Y, Roberts GC, Lemyre PN, Treasure D (2003). Perceived motivational climate in male youth soccer: relations to social-moral functioning, sportpersonship and team norm perceptions. Psychology of Sport and Exercise, 4, 397-413.

Palou P, Borràs PA, Ponseti FX, Garcia-Mas A, Cruz J (2003). Comportamientos de fairplay en estudiantes de magisterio de educación fisica. [Behaviours related to fairplay in physical education students]. Revista de Psicologia del Deporte, 12, 81-91.

Pilz GA (1995). Performance sport: education in fair play? Some empirical and theoretical remarks. International Review for the Sociology of Sport, 30, 391-418.

Rimé B, Leyens JP (1988). Violence dans les stades: la réponse des psychologues. La Recherche, 19, 528531.

Russell GW (1993). The social psychology of sport. New York: Springer-Verlag .

Shields DL, Bredemeier BJ (2001). Moral development and behaviour in sport. In R Singer, H Hausenblas, CM Janelle (Eds.). Handbook of sport psychology (pp. 585-603). New York: Wiley.

Shields DL, Bredemeier BL, LaVoi NM, Power CF (2005). The sport behavior of youth, parents, and coaches: the good, the bad \& the ugly. Journal of Research on Character Education, 3(1), 43-59.

Silva JM (1981). Normative compliance and rule violating behavior in sport. International Journal of Sport Psychology. 12, 10-18.

Silva JM (1983). The perceived legitimacy of rule violating behavior in sport. Journal of Sport Psychology. 5, 438-448.

Smith MD (1983). Violence and Sport. Toronto: Butterworths.

Stephens DE, Bredemeier BJ (1996). Moral atmosphere and judgements abaout agression in girls soccer: relationships among moral and motivational values. Journal of Sport and Exercise Psychology, 18, 158173.

Stornes T (2001) Sportspersonship in elite sports: on the effects of personal and environmental factors on the display of sportspersonship among elite male handball players. European Physical Education Review, 7 (3), 281-301.

Tenenbaum G, Stewart E, Singer RN, Duda J (1997). Aggression and violence in sport: An ISSP position stand. The Sport Psychologist, 11,1-7.

Torregrosa M, Cruz J (1999). Diferencias de arbitraje entre la liga de fútbol profesional (LFP) y la premiere league $(P L)$ : ¡cuestión de cantidad o de calidad? [Officiating differences between the LFP and PL: a matter of quantity or quality?]. In F. Guilen (Ed.) La psicologia del deporte en España al final del milenio. (pp.575-582). Las Palmas de Gran Canaria, Spain: Universidad de Las Palmas.

Torregrosa M, Lee M (2000). El estudio de los valores en psicología del deporte.[ The study of values in sport psychology] Revista de Psicologia del Deporte, 9, 1-2, 71-83.

Torregrosa M, Mimbrero J, Boixadós M, Cruz J (1996). Comportamientos relacionados con el fairplay en futbolistas de iniciación y profesionales. [Behaviours related with fair play in youth and professional football players]. In R Sanchez (Ed.) La actividad física y el deporte en un contexto democratico (19761996). (pp.87-95). Pamplona: AIESAD. 